\title{
Performance of Indian Mutual Fund Schemes
}

\author{
G. Indhumathi, M. Babu, J. Gayathri
}

\begin{abstract}
Risk, diversification, features of investment avenues, and tax benefit are the factors considered by the investors in their decision making. The convenience of investing in small proportions and tax benefits attracts the investors towards mutual fund investments. The studies prove that market timing ability of fund managers drives the mutual fund scheme performance. This assessment of the above factors would help to the investors in their choice of mutual funds. 36 Indian Mutual Funds Schemes were assessed using the Sharpe, Treynor, Jensen's measure from January to June 2019. L\&T Liquid Fund-Direct (Growth), L\&T Low Duration Fund-Growth and Edelweiss Large Cap Fund Direct (Growth) performed well.
\end{abstract}

Keywords: Jensen Ratio, Mutual Funds, Risk and Return, Sharpe and Treynor Ratios

\section{INTRODUCTION}

The investor's resources were collected by the Asset Management Company for investment in various avenues. The return for the investors depends on the appreciation in Net Asset Value (NAV) of mutual fund. Thus the benefits flowing from fund performance was shared by the investors in proportion to their mutual fund units. The investment in stock, bond, and money market provides diversification benefits to the mutual funds. Diversification reduces market risk compared to individual securities.

\section{REVIEW OF LITERATURE}

R. Ravikumar (2013) analyzed the equity based funds during and found that the average performers were Reliance and UTI, worst performer was SBI mutual fund. M.M.Goyal (2015) found that all the sample equity diversified mutual fund schemes provided higher and better average return than the market. P. Sathis and K.Sakthi Srinivasan (2016) used average rate of return, standard deviation, beta, correlation, regression and risk adjusted techniques for analyzing the mutual fund schemes. Ratish Gupta and Shruti Maheshwari (2017) suggested the small investors to

Revised Manuscript Received on July 22, 2019. Mother Teresa Women's University, Kodaikanal. India.

E-mail: indhunila2000@gmail.com.

Dr. M.Babu, Assistant Professor, Bharathidasan School of Management, Bharathidasan University, Thiruchirappalli, Email: drbabu@bdu.ac.in.

Dr. J. Gayathri, Assistant Professor, Department of Commerce and Financial Studies, Bharathidasan University, Thiruchirappalli,

E-mail: gayajayapal@gmail.com.
Dr.G.Indhumathi, Assistant Professor, Department of Commerce,

combine large cap and mid cap funds in their portfolio. O.V.A.M.Sridevi (2018) compared the performance of balanced mutual fund schemes between mid cap and small cap fund on the basis of return and risk evaluation during 2016 to 2017. The analysis has reported diversified and varied results.

V.Chitra and T.Hemalatha (2018) analyzed performance in comparison to BSE-Sensex and the monthly yield on 91-Day $\mathrm{T}$ bills for risk-free rate. From the result, the standard deviation and beta value was also low for UTI Dividend Yield fund. The investor can invest in UTI Dividend Yield fund to get regular income.

\section{NEED OF THE STUDY}

By bringing in the collected funds, the mutual funds contribute to the development of an economy. The efficient performance of mutual fund would bring in further money. The risk and return of the mutual funds, their performance in comparison to the market, their positioning, their ability to meet the investor expectation level were analysed in this study.

\section{OBJECTIVES OF THE STUDY}

The present study aims to evaluate the mutual fund schemes in India using standard performance models like Sharpe, Treynor and Jensen.

\section{METHODOLOGY OF THE STUDY}

The duration of the study is six months starting from $1^{\text {st }}$ January 2019 to $30^{\text {th }}$ June 2019. The top performing 36 mutual funds schemes in January 2019 were selected. For evaluating the performance of mutual funds, the daily net asset value (NAV) data were collected from AMFI and NSE websites. Risk free return is proxy with 91 days T-Bill rate. NSE Nifty Index has been used as benchmark portfolio.

\section{TOOLS USED FOR ANALYSIS}

The performance of mutual fund schemes has been evaluated by using Treynor ratio, Sharpe ratio and Jensen ratio.

\section{A. The Treynor measure}

$$
T_{p}=\frac{r_{p}-r_{f}}{\beta_{p}}
$$

Where, $\mathrm{T}_{\mathrm{p}}$-Treynor Performance Measure, $\mathrm{r}_{\mathrm{p}}$ - portfolio

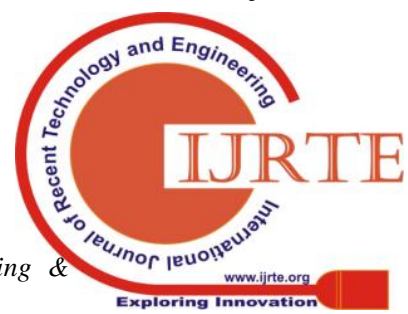


return, $\mathrm{r}_{\mathrm{f}}-$ Risk free rate and $\beta_{\mathrm{p}}-$ Market risk of $\mathrm{r}_{\mathrm{p}}$

\section{B. The Sharpe Measure}

$$
S_{p}=\frac{\bar{r}_{p}-r_{f}}{\sigma_{p}}
$$

Where, $\mathrm{S}_{\mathrm{p}}$-Sharpe performance Measure, $\mathrm{r}_{\mathrm{p}}$ - Average return of Portfolio $\mathrm{p}, \mathrm{r}_{\mathrm{f}}$ - Risk free rate, $\sigma_{p}$-Total risk of $\mathrm{r}_{\mathrm{p}}$

While a high and positive Sharpe Ratio shows a superior risk-adjusted performance of a fund, a low and negative Sharpe Ratio is an indication of unfavorable performance.

\section{The Jensen measure}

If an asset's return is even higher than the risk adjusted return, that asset is said to have "positive alpha" or "abnormal returns". Investors are constantly seeking investments that have higher alpha.

Jensen's Alpha $=$ Portfolio Return $-[$ Risk Free Rate +

Portfolio Beta * (Market Return - Risk Free Rate)]

\section{ANALYSIS OF PERFORMANCE OF MUTUAL FUNDS SCHEMES IN INDIA}

Table-I presents the results of top performing Indian Mutual Fund Schemes during the months of January to June 2019. From the table it is clear that, L\&T Liquid Fund -D $(G)$, L\&T Low Duration Fund-G and Edelweiss Large Cap Fund Direct $(\mathrm{G})$ earned high return according to Sharpe Ratio (0.6537), Treynor ratio (5.3559) and Jensen measure (0.0338) respectively during the study period. It is also found from the table that Franklin Build India Fund-D $(G)$ with respect to Sharpe Ratio and Treynor ratio and L\&T Infrastructure (G) under Jensen Ratio showed poor performance than other schemes. All the Sectoral funds selected for this study earned negative returns using all the three ratios. The schemes selected for the study belongs to Short Duration Fund, Gilt Fund (except Edelweiss Government Securities Fund Regular (G) in Sharpe ratio), Liquid Fund and ETFs (except Kotak Nifty ETF in Treynor ratio) were recorded positive returns in Sharpe Ratio, Treynor ratio and Jensen measure.

The schemes selected under Multi Cap fund, ELSS (Equity Linked Savings Scheme) and Aggressive Hybrid Fund were recorded negative return during the study period under Treynor and Jenson measures and Conservative Hybrid funds (except BNP Paribas Conservative Hybrid Fund-D $(G)$ ) under all the three measures. The overall result found that the 36 sample mutual fund schemes provided positive return under Sharpe measures in the study period.

\section{VIII.FINDINGS OF THE STUDY}

The following are the major findings of the study.

- From the analysis of top performing Indian Mutual Fund Schemes during the month of January to June 2019, it is observed that L\&T Liquid Fund -D $(G)$, L\&T Low Duration Fund-G and Edelweiss Large Cap Fund - Direct (G) yielded highest return according to Sharpe Ratio, Treynor ratio and Jensen measure (0.6537, 5.3559 and 0.0338 respectively).

- Franklin Build India Fund-D(G) earned lowest return than all other schemes with respect to Sharpe and Treynor ratios and L\&T Infrastructure $(\mathrm{G})$ recorded negative performance under Jensen's performance measure during the study period.

- The sample schemes covers under Large Cap Funds (4 schemes), Short Duration Fund (2 schemes), Gild Fund (2 schemes), Liquid Fund (3 schemes) and ETFs (1 schemes) were recorded positive returns during the study period.

- Sample schemes from Sectoral Fund and Conservative Hybrid Fund recorded negative returns under Sharpe Ratio.

- The study found that 11 sample mutual fund schemes earned positive return and 7 schemes earned negative returns under Sharpe, Treynor and Jenson performance measures during the study period.

\section{SUGGESTIONS OF THE STUDY}

- Due weight-age should be given to risk and return in making the choices.

- The regulations in relation to the mutual fund would be the prime concern for the investor's decision.

\section{CONCLUSION}

The profitable investments were the outcome of proper selection and continuous appraisal of mutual funds schemes. The results prove that the growth oriented mutual funds have not performed better. The degree of diversification varies widely among the mutual fund schemes. The risk lies with the less diversified portfolio. This shows the poor performance of fund managers in terms of market timing and selectivity ability.

\section{REFERENCES}

[1]. Avadani V A, Security Analysis and Portfolio Management. Mumbai: Himalaya Publishing House, 1998.

[2]. Bhole L M, Mutual Funds, Financial Institutions \& Markets. New Delhi: Tata McGraw Hills publishing Limited, 1999.

[3]. Chandra, Prasanna, Investment Analysis and Portfolio Management, 2nd Edition, New Delhi: Tata McGraw-hill Publishing Company limited, 2005.

[4]. Sadhak H, Mutual Funds in India - Marketing strategies \& Investment practices. New Delhi: Sage Publication, 1997.

[5]. Bhagyasree.N and Kishori B, "Performance evaluation of Mutual Funds Schemes in India". International Journal for Innovative Research in Science \& Technology, vol.2, Issue 11, 2016, pp. 812-816.

[6]. Chitra.V and Hemalatha T, "Risk \& return analysis of performance of Mutual Fund Schemes in India". International Journal of Applied Research, 2018, pp. 279-283.

[7]. Goyal M M, "Performance evaluation of top ten Mutual Fund in India". Indian Journal of Commerce \& Management Studies, vol. VI, Issue 1, 2015, PP 51-55.

[8]. Ravikumar R, "Analysis of the risk and return relationship of Equity based Mutual Fund in India". International Journal of Advancements in Research \& Technology, vol.2, Issue 8, 2013, pp. 289-295.

[9]. Ratish Gupta and Shruti Maheshwari, "An empirical study on performance of diversified Equity Mutual Funds with special reference to large cap and mid cap funds". AIMA Journal of Management \& Research, vol. 11, Issue 3/4, 2017, pp. 01-11.

[10]. Sathis P and Sakthi Srinivasan K, "Performance evaluation of selected open ended Mutual Fund Schemes in India: An empirical study". Global Management Review, vol. 10, Issue 3, 2016, pp. 93-105. 
[11]. Sridevi O V A M, "Performance analysis of Mutual Funds-A study on selected mid cap and small cap funds". International Journal of Business and Management Invention, vol.7, Issue 7, 2018, pp. 06-12.

[12]. www.amfiindia.com

[13]. www.nseindia.com

Table -I: Sharpe ratio, Treynor Ratio and Jensen Measure of Mutual Fund Schemes for January to June

\begin{tabular}{|c|c|c|c|c|c|c|c|}
\hline & & 2019 & & & & & \\
\hline \$L. & & Sharpo & Ran & Tryyor & Res & Jesen & Ren \\
\hline . b. & $\begin{array}{l}\text { Mhrul Fud Scheme } \\
\text { Multicop Fud }\end{array}$ & Ratio & 1 & Reio & 1 & Recio & 1 \\
\hline 1 & 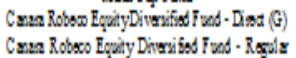 & 0.0443 & 19 & .000074 & 16 & $\cdot 0.0012$ & 20 \\
\hline 2 & & 0.0400 & 20 & .00105 & 18 & 0.0010 & 19 \\
\hline 3 & 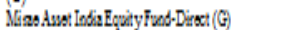 & 0.0266 & 26 & .00176 & 19 & .00196 & 30 \\
\hline 4 & 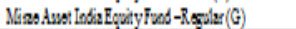 & 0.030 & 28 & .0003 & 23 & .00102 & 24 \\
\hline$s$ & 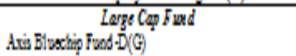 & 0.0003 & 10 & 0.0361 & 10 & 0.0300 & 2 \\
\hline 6 & Asu Bluxtip Fad $(G)$ & 0,0001 & 11 & 0,0026 & 11 & 0.0243 & 3 \\
\hline 7 & 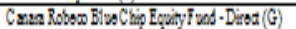 & 0,0729 & 13 & 0.0092 & 12 & 0.0141 & 4 \\
\hline 8 & 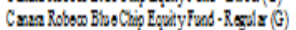 & 0.0654 & 14 & 0.2351 & $\ddot{q}$ & 0.0075 & 13 \\
\hline 9 & 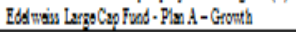 & 0.0584 & 16 & .00092 & 17 & .0 .0024 & 2. \\
\hline 10 & 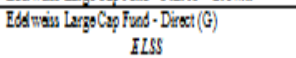 & 0.0615 & 15 & 0.1670 & 32 & 0.038 & 1 \\
\hline 11 & Ienvoco lofa Tax Pan Dist G) & 0.029 & 23 & .00186 & 21 & .00181 & 29 \\
\hline 12 & Inveso Iadia Tux Paracronth & 0,029 & 24 & .00181 & 20 & .00002 & 31 \\
\hline 13 & 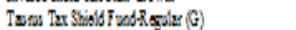 & 0.0333 & 7 & .0033 & 24 & .00179 & $\ddot{2}$ \\
\hline 14 & 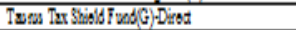 & 0,0696 & 25 & .00006 & 212 & .001 .4 & 27 \\
\hline 15 & 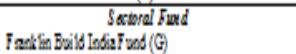 & .00569 & 33 & .00685 & 28 & .00661 & 34 \\
\hline 16 & 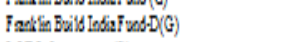 & .7088 & 36 & .30 .9961 & 36 & .00146 & 26 \\
\hline 17 & LXI lafusuratue (G) & .0039 & 33 & .0 .1093 & $3 !$ & 0.006 & 36 \\
\hline is & LST lafubustes Fivad $\cdot \mathrm{DG}$ () & .00087 & 34 & .0 .1051 & 30 & .00987 & 39 \\
\hline & Agpersinu Hyord Fad & & & & & & \\
\hline 19 & 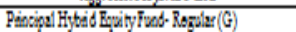 & .00090 & 29 & .00388 & 26 & .00381 & 33 \\
\hline 20 & Pincigal Hytad Brityfuad - Dirot (G) & 0.0476 & 17 & .0 .0327 & 28 & .0024 & 32 \\
\hline 21 & 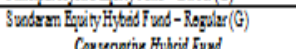 & 0.0457 & 18 & .00039 & IS & 0.0015 & 18 \\
\hline n & 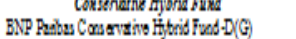 & 0.0397 & 21 & 0.0007 & 13 & 0.0017 & 21 \\
\hline 23 & 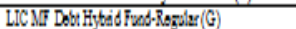 & .00394 & 32 & .000334 & 29 & .00140 & 25 \\
\hline 24 & 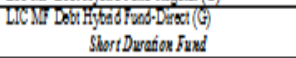 & .00196 & 31 & .00645 & 27 & .00102 & 23 \\
\hline 2 & LXI Lom Diatisa f vadG & 03342 & $?$ & 53359 & $T$ & 0.0062 & 16 \\
\hline 26 & 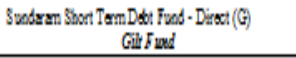 & 03319 & 8 & 3.479 & 2 & 0.0003 & 12 \\
\hline 77 & 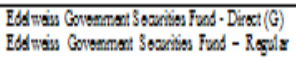 & 0.0315 & 2 & 0.6633 & 6 & 0.0104 & 10 \\
\hline 28 & & .00117 & 30 & 0.5333 & $?$ & 0.0087 & 11 \\
\hline 29 & 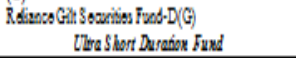 & 0.0918 & 9 & 0.7447 & 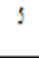 & 0.0072 & 14 \\
\hline 30 & 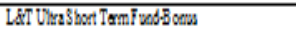 & 0.5140 & 4 & .57664 & 34 & 0.0105 & 9 \\
\hline 31 & LST Uliashor Teminad (G) & 0.5093 & 3 & .69628 & 35 & 0.0106 & 8 \\
\hline 32 & LXI Tha Sbost Temivad D(G) & 0.4941 & 6 & -49916 & 33 & 0.0120 & 1 \\
\hline 33 & 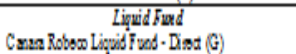 & 0.6435 & 3 & 0.47273 & 8 & 0.0106 & $?$ \\
\hline 34 & LST Liendi ivad $(G)$ & 0.6486 & $i$ & 21814 & 4 & 0.0066 & is \\
\hline 35 & $\begin{array}{r}\text { LeT Liquid inad D(G) } \\
\text { ITFs }\end{array}$ & 0.6337 & 1 & 22342 & 3 & 0.0111 & 6 \\
\hline 36 & Kond NAyETI & 0.0786 & 12 & .00003 & 14 & 0.0056 & 17 \\
\hline
\end{tabular}

Source: Secondary Data

\section{AUTHORS PROFILE}

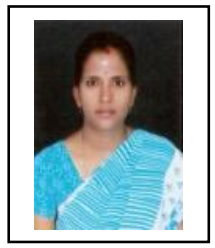

Dr.G.Indhumathi is presently working as Assistant Professor of Commerce, Mother Teresa Women's University, Kodaikanal, Tamil Nadu. She holds Master of Commerce Degree and Doctorate from Bharathidasan University, Tiruchirappalli, Tamil Nadu. She has published 38 articles in reputed National and International Journals, One Book and 6 chapters in Edited Books. She has attended/presented more than 150 research papers in various Seminars, Conferences and Workshop at National and International level. She has also organized various Seminar and Workshop at National and International level. She has made significant contributions to research in the field of Corporate Finance and Financial Services and Markets. She can be reached at: indhunila2000@gmail.com.

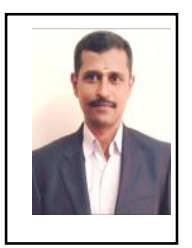

Dr. M. Babu is presently working as Assistan Professor in Bharathidasan School of Management, Bharathidasan University, Tiruchirappalli, TamilNadu. He holds MBA Degree from the University of Madras and Doctorate from Bharathidasan University, Tiruchirappalli, TamilNadu. He has published 71 articles in reputed peer-reviewed National and International Journals and 11 chapters in Edited Books. He has attended/presented the research papers in various Seminars, Conferences and Workshop at National and International level. He has also organized various Seminar and Workshop at National and International level. He has made significant contributions to research in the field of Financial Services and Markets, Financial Engineering and Behavioural Finance. He can be reached at: drbabu@bdu.ac.in

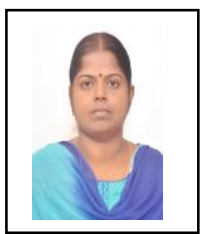

Dr. J. Gayathri is presently working as Assistan Professor in Commerce and Financial Studies, Bharathidasan University, Tiruchirappalli, TamilNadu. Her area of specialization is Finance and International Finance. She has 11 years of teaching experience. She holds M.Com, M.B.A and $\mathrm{Ph} . \mathrm{D}$ Degrees. She has published 42 articles in reputed peer-reviewed National and International Journals and 9 chapters in Edited Books. She has participated in 43 workshops/ seminars and presented papers in 58 seminars/ conferences at National and International level. She has also organized 8 Seminars and Workshop at National and International level. 